\title{
Effectiveness of Dessimination of Rahmatan Lil 'Alamin Values Using Problem-Based Learning Methods on Ya Badi' Dhikr and Ta'lim Assembly, Kalitirto, Berbah, Sleman, Yogyakarta
}

\author{
Lukman \\ Department of Islamic Education \\ Islamic University of Indonesia \\ Yogyakarta, Indonesia \\ lukman.ahmadirfan@uii.ac.id
}

\author{
Badrun Kartowagiran \\ Doctoral Program \\ Yogyakarta State University \\ Yogyakarta, Indonesia \\ kartowagiran@uny.ac.id
}

\author{
Muzhoffar Akhwan \\ Department of Islamic Education \\ Islamic University of Indonesia \\ Yogyakarta, Indonesia \\ muzhoffar@uii.ac.id
}

\begin{abstract}
It is found that Problem Based Learning (PBL) can be well-used for the dissemination of Rahmatan lil 'alamin values. It is one of the options to facilitate Muslims to be a tolerant person. This research conducted towards Ya Badi' Dhikr and Ta'lim Assembly because they faced varied differences and lacked of understanding to deal with it. Therefore, the understanding of Islam Rahmatan lil 'alamin as a foothold in attitude and behaviour among differences is one of terms that should be owned by Muslims. Discussion method based on PBL are used on this research. From the results of interviews and observations, it was found that dissemination of the values of Rahmatan lil 'alamin are well implemented. Subjects are increasingly able to work on the land, have an increasingly harmonious relationship in the family, the neighbors, others which non-Muslims, and become more honest and diligence on their profession or work.
\end{abstract}

Keywords-Dissemination, Rahmatan Lil 'Alamin, Problem Based Learning

\section{INTRODUCTION}

Humans interact with each other different roles: when at home, they act as family members, community members, and worshipers; in the workplace, they act as a leader, employee, cooperative member and other; while in social media playing theirself with all the complexity of their life. Meeting the demands of these different roles, each individual needs harmony and peace in carrying out all of their roles.

Religious rules are signs to harmonize and reconcile the human soul, but understanding that is too extreme and will also make religion no longer on the straight path. Beliefs and charity in Islam lead to personalities with moral character. The Qur'an mentions these types of people who have akhlakul karimah with moeslims, mukmin, mukhlis, muhibbin, mustaghfirin, and mutathohhirin. These types, bur not denying the types that have not been mentioned, are dynamic conditions that formulate the consciousness that arises from an enlightened mind by a calmness heart.

This awareness can arise with the ability to digest their condition in every role that covers it with confirmation of religious teachings. Not everyone is required to understand and practice with a very high and profound understanding. A person who acts as a leader is certainly different from a worker in applying religious teachings, a rich person is certainly different in applying religious teachings. Maybe the form of implementation is the same, but the mental condition that covers it is certainly different. This is what is called contextually religious.

To mention the rationale above is the Word of Allah SWT in Sura al-Mulk verse 2, that humans will be tested to show their toughness in good deeds. Charity of a rich person is certainly different from someone who is in the faqir. A rich person must pay zakat, while a faqir must be patient and not give up. The basis of the hadith is that a person who has parents who must be cared for is not required to fight on the battlefield, but his jihad is to take care of his parents. These are the forms of the values implied in rahmatan lil 'alamin, the religion which full of blessing.

Every role which the responsibility of a person should be understood that they are sued not the same as other individuals. By contextualizing religious teachings like this, it does not happen that someone forces himself to worship with others. If this is not put right, there will be competition in applying religious teachings. This applies religion based on the assessment of each other, even though religion is really for devotion to Allah SWT. Competition in religion will bring about an uneasy mental state in the form of behavior demeaning others and maintain self-esteem.

This contextual religion is not in the core forms of worship which the Prophet Muhammad SAW exemplified such as prayer, zakat, fasting, and Hajj in absolute terms. On the contrary, these core services have been understood as possible in the context of a worshiper, such as prayers can be called qoshor, zakat can be done using rice, wheat, corn in accordance with the daily context of the cultural background of the worshipper, fasting can be replaced, pilgrimage can be with the Tamattu, Ifrod, and Qiron models.

Based on the thoughts above, then preaching and religious learning must be done contextually. This requires a religious teacher to have experience in delivering dakwah and learning. This is clearly stated in Sura Al-Asr verse 3, that someone who has the truth and patience should have faith and do good deeds first. Experienced first in faith and amal, before preaching and teaching.

In the field of learning that has been tested there is a learning model that allows a teacher to do contextual learning, namely Problem Based Learning (PBL). PBL is a learning model that presents contextual (real world) problems so that 
to motivate learners in finding solutions. The solution offered is in accordance with the theory that has been tested or the verses of the Qur'an, Hadith and the intellectual property of ulama.

Based on the above framework of thinking, researcher apply PBL in the community service activities of the dissemination of rahmatan lil amin 'alamin values in the assembly of Ya Badi Dhikr and Ta'lim Berbah Sleman DIY.

\section{METHODOLOGY}

This research is a field research study with a qualitative approach. Researchers observe and participate directly in small social scale research and observe local culture. This research involved researchers directly in the association of several groups of people who had a distinctive appeal. In the field, researchers individually speak and directly observe the people they are studying through interactions for several months or years learning about them, their life history, their habits, their hopes, fears, and dreams. This study intends to describe the phenomenon of the "real" values of rahmatan lil amin alamin as a result of the dedication of the research community, symptoms or circumstances.

The place of the research is the Dhikr and Taklim Ya Badi Assembly in Kalitirto Village, Berbah District, Sleman Regency, Special Region of Yogyakarta, Indonesia. The informants were pilgrims from the Dhikr and Taklim Ya Badi assembly. The sample is determined purposively (deliberately or with consideration) so that the study sample does not need to represent the population. The consideration of the sample is not based on aspects of population representation in it, but it is more on the ability of the sample (informant) to supply information about the values of rahmatan lil amin alamin.

This research used two methods of Data Collection Techniques which Observation and Interview. Observations in this study were carried out in an involved (participatory) or non-participatory manner. That is, the observation involved is a type of observation that involves researchers in the activities of people who are the target of research without causing changes in the activities or activities in question and of course in this case the researcher does not cover himself as a researcher. Also, Interviews are conducted with no intention to focus on questions that are asked in an unstructured manner, but are always centered on a particular subject matter.

The collected data then processed by using the following methods: (1) Editing. Data checking (editing), before processing data, it is necessary to check the data first. In other words, data or information that has been collected both from the results of primary and secondary sources are examined once again and corrected if there are still things that are wrong or still doubtful; (2) Coding. Making code (coding) the edited data, as an attempt to simplify the data, namely by giving categorization to the data; (3) Descriptive analysis of the results of library studies and in depth; (4) Content Analysis (content analysis). This Content Analysis, although commonly used in quantitative research, is also often used in qualitative research, mainly used when analyzing various documents that we make as the main reference.

\section{RESULTS}

\section{A. PBL in Community Services}

According to Arends (1987) PBL is a teaching method with a real problem-solving focus, a process by which learners carry out group work, feedback, discussion, which can serve as a springboard for investigation and a final report. The definition given by Aurends is slightly different from $\mathrm{Ni}$ Made's opinion which defines PBL as learning that teaches learners how to use concepts and interaction processes to assess what they know, identify what they want to know, gather information and collaboratively evaluate the hypothesis based on data that has been collected (2008). Both of these definitions according to the authors complement each other as a more comprehensive learning procedure, that PBL is a learning model that focuses on real problem solving, based on concepts and interaction processes in related fields to assess what they know, in group work, and then discussed to get feedback, as a stepping stone for investigations and final reports.

Practically PBL organizes teaching around questions and problems that are socially important and have personal meaning for worshipers or learners. The problem being investigated was chosen because the solution required worshipers to explore many subjects. Authentic investigations try to find real solutions to real problems. The learner must analyze and determine the problem, develop hypotheses and make predictions, collect and analyze information, carry out experiments (whenever possible), make inferences, and draw conclusions. Before the discussion begins in class, students are first asked to observe a phenomenon. Then students are asked to formulate the problems that arise. At the next meeting, the instructor motivated the worshiper to think critically in solving the problems. Instructors direct pilgrims to ask questions, prove assumptions by observation, and listen to opinions that are different from those worshipers and then draw conclusions about Islam Rahmatan lil 'Alamin.

The adaptation of PBL above is slightly different from the steps or syntax in using the PBL model according to Nisaul Azmi Hajar et al. (2016) namely: 1) Introduction of problems to students based on material taught to students. 2) Students are organized in several groups to conduct discussions in solving problems. 3) The results of student group analysis were presented to other student groups. 4) Teachers help students to reflect on the results of investigations conducted by students.

In one of the studies the authors did prove that PBL can improve students' adaptability in responding to the needs of children with special needs (Lukman Ahmad Irfan, 2017). This inspired the writer to apply PBL in the community service with the subject of the general public, in this case worshipers in the Ya Badi Dhikr and Ta'lim Assembly Kalitirto Village, Berbah District, Sleman Regency, Yogyakarta Special Region.

The dedication carried out by the author adopting PBL was done with a large PBL design with the following stages, namely: (1) Introduction of the problem to the subject of service; (2) The subject is directly invited to discuss; (3) The results of the discussion are strengthened and deepened by the instructor; (4) instructor help the subject to reflect on the subject matter. 
At the Recognition stage the subject is very excited because the rahmatan lil 'alamin problem is in contact with the subject's daily life and is often revealed in publications by mass media such as newspapers and television. The discussion opened by a question, the writer starts with why Islam is called the rahmatan lil 'alamin religion even though in reality the Muslim life in Indonesia and the Middle East give fearsome belief with various conflicts and wars. Many Muslims do actions that do not show that they are in a state of grace by committing corruption, theft, cheating, hatred, imposing their will on their families, and destroying the universe. With an introductory dialogue, many of the contradictions between Islam and Muslims are very well understood by the subjects and they are taken seriously to discuss them. This dialogue provides their understanding that there are interesting issues but it is not too difficult to answer because the servants provide feedback on the emphasis on the word Islam and Muslims. Methodically, this is very important to turn on PBL.

At a later stage, the author's discussion points to organizing problems in several problem groups. If the class is divided into groups of students according to the problem, this service is replaced by dividing into the category of discussion problems. This is done by the author to provide a sustainable direction for discussion in solving problems. During this introductory dialogue the author divides the categories into 9 (nine) main issues, namely: (1) Verses related to Rahmatan lil 'Alamin; (2) Hadith related to Rahmatan lil 'Alamin; (3) Rahmatan lil 'Alamin Values; (4) Rahmatan lil 'Alamin neighborhood values; (5) Rahmatan lil 'Alamin in the profession; (6) Rahmatan lil 'Alamin values with the Environment; (7) Rahmatan lil 'Alamin fellow human beings values; (8) Rahmatan lil 'Alamin family values; (9) Rahmatan lil 'Alamin praying values. These nine main issues are the continuation of this discussion the author poured in the dedication material.

\section{B. Dedication Material}

The dedication material presented by the author covers 10 (ten) topics, namely: (1) Introductory Dialogue; (2) Paragraphs relating to Rahmatan lil 'Alamin; (3) Hadith related to Rahmatan lil 'Alamin; (4) Rahmatan lil 'Alamin Values; (5) Rahmatan lil 'Alamin neighbourhood Values; (6) Rahmatan lil 'Alamin in the Profession; (7) Rahmatan lil 'Alamin Values with the Environment; (8) Rahmatan lil 'Alamin values of fellow human beings; (9) Rahmatan lil 'Alamin family values; (10) Rahmatan lil 'Alamin praying Values.

\section{1) Introduction Dialogue.}

As an introduction the instructor said that Islam is a religion that is Rahmatan lil 'Alamin, with the meaning that Islam is a religion of mercy, love for fellow human beings and the universe as well as a counter to violence and aggressiveness towards others and the universe. However, the social reality of why Muslims internally even interferes with other Muslims is the fact that many occur in Indonesia and outside Indonesia. Instructor provide examples of ISIS and other radicalism.

Related to the meaning of Rahmatan lil 'Alamin the servant asserted that Allah SWT has a good name, among them are Ar-Rahman and Ar-Rahim. These two good names are one root word with Rahmatan lil 'Alamin. The servant conveyed the meaning of the two words to explain and emphasize about Rahmatan lil 'Alamin. The interpretation of the rahmatan lil 'alamin verse the author points to the interpretation of the Ahlu Sunnah movement which is more moderate (Lukman, 2016).

2) Verses related to Rahmatan lil 'Alamin (Meeting 2)

Indeed, all the verses in the Qur'an are rahmatan lil 'alamin. Some are explicitly related to Rahmatan lil 'Alamin contained in Al Quran Surat Al Anbiya'/21 verses 107 and AlQashash/28 verse 86: "We have not sent you, [O Muhammad], except as a mercy for the worlds." (QS. Al Anbiya'/21: 107). "And you were not expecting that the Book would be conveyed to you, but [it is] a mercy from your Lord. So do not be an assistant to the disbelievers". (Al-Qashash/28: 86)

\section{3) Rahmatan lil 'Alamin Hadiths (Meeting 3)}

Hadith related to Rahmatan lil 'Alamin include: From Abu Hurairah, may Allah be pleased with him, he said, "The Messenger of Allah had been asked," O Messenger of Allah, do accidents/destruction for the polytheists! "He replied," Verily I am not sent as a condemnation, in fact I am sent only as a mercy. "(HR. Imam Muslim, No. 2599). In a hadith the history of Imam Muslim is mentioned "Verily Allah Subhanahu wa Ta'ala has 100 blessings, He sent down a mercy to jinn, humans, livestock and lions. With that one grace, among them they protect each other, love one another and with one mercy the wild animals protect their children, And Allah ends the other 99 mercy. And will be given to His servants on the Day of Judgment. (H.R Muslim).

\section{4) Rahmatan lil 'Alamin Values (Meeting 4)}

The instructor believes that Rahmatan lil 'Alamin's values are generally summarized in the five objectives of Islamic law or maqoshidusy-syar'iy, namely:

\section{a) Hifdz Ad-Din (Maintaining Religion)}

God commands us to keep trying to uphold religion, the word in the letter of Shura ': 13:

"He has ordained for you of religion what He enjoined upon Noah and that which We have revealed to you, [O Muhammad], and what We enjoined upon Abraham and Moses and Jesus - to establish the religion and not be divided therein. Difficult for those who associate others with Allah is that to which you invite them. Allah chooses for Himself whom He wills and guides to Himself whoever turns back [to Him]."

\section{b) Hifdz An-Nafs (Maintaining the Soul)}

Regarding this matter we can find in the word of Allah in QS Al-Baqarah verses 178-179 which read:

"O you who have believed, prescribed for you is legal retribution for those murdered - the free for the free, the slave for the slave, and the female for the female. But whoever overlooks from his brother anything, then there should be a suitable follow-up and payment to him with good conduct. This is an alleviation from your Lord and a mercy. But whoever transgresses after that will have a painful punishment. And there is for you in legal retribution [saving of] life, O you [people] of understanding, that you may become righteous."

\section{c) Hifdz Al'Aql (Maintaining Intellect)}

Allah SWT says in Q.S. Al-Baqarah verse 164 which reads: "Indeed, in the creation of the heavens and earth, and 
the alternation of the night and the day, and the [great] ships which sail through the sea with that which benefits people, and what Allah has sent down from the heavens of rain, giving life thereby to the earth after its lifelessness and dispersing therein every [kind of] moving creature, and [His] directing of the winds and the clouds controlled between the heaven and the earth are signs for a people who use reason."

\section{d) Hifdz An-Nasb (Maintaining offspring)}

As the word of Allah ta'ala: "And if you fear that you will not deal justly with the orphan girls, then marry those that please you of [other] women, two or three or four. But if you fear that you will not be just, then [marry only] one or those your right hand possesses. That is more suitable that you may not incline [to injustice]."(Surat an-Nisa: 3 ).

\section{e) Hifdz Al-Maal (Maintaining Property)}

Islamic protection of one's property is reflected in His words: "O you who have believed, do not consume one another's wealth unjustly but only [in lawful] business by mutual consent. And do not kill yourselves [or one another]. Indeed, Allah is to you ever Merciful.” (Q.S. An-Nisa: 29).

\section{5) Rahmatan lil Alamin neighbourhood values (Meeting} 5)

a) The guidance of Rahmatan lil 'Alamin neighbourhood values

In Surat An-Nisa verse 36, Allah Ta'ala says, which means: Worship Allah and associate nothing with Him, and to parents do good, and to relatives, orphans, the needy, the near neighbor, the neighbor farther away, the companion at your side, the traveler, and those whom your right hands possess. Indeed, Allah does not like those who are self-deluding and boastful. (Surat an-Nisa: 36).

\section{Hadith}

b) Guidance neighboring Rahmatan lil 'Alamin in

i. The neighbor is almost like an heir Rasulullah SAW said: "Gabriel always advised me about neighbors, so I thought that the neighbor would get a share of inheritance" (Narrated by Bukhari 6014, Muslim 2625).

ii. The Best Neighbors will be on the Side of Allah SWT The Messenger of Allah said: "The best friend by Allah is the best in his attitude towards his friend. The best neighbor in the sight of Allah is the best of his attitude towards his neighbor "(HR. Tirmidhi 1944, Abu Daud 9/156).

iii. Neighboring in Rahmatan lil 'Alamin by glorifying it "Whoever believes in Allah and the final day, he should glorify his neighbor" (Narrated by Bukhari 5589, Muslim 70).

iv. Should not misbehave or commit crime to neigbor The Messenger of Allah said: "By Allah, do not believe, do not believe, do not believe. Some ask: "Who is O Messenger of Allah?" He replied: 'People whose neighbors are not safe from carrying it (the crime)' "(Narrated by Bukhari 6016, Muslim 46).

v. Neighboring well exceeds the Night and Sunnah Prayers A friend said: "O Messenger of Allah, the Fulanah often prayed at night and fasted. But his verbal has hurt his neighbor. The Messenger of Allah said: 'There is no good to him, he is in hell' "(HR. Al Hakim in Al Mustadrak 7385).

vi. Don't Let Hunger Neighbors The Messenger of Allāh da said: "Not a believer, a person who is full of his stomach while his neighbor is starving" (Narrated by Al Baihaqi in Sunan Al Kubra 18108).

vii. Sharing Food with Neighbors Rasulullah SAW said: "If you cook vegetables, multiply the broth. Then look at your neighbor's family, give some of them to them in a good way "(HR Muslim 4766).

viii. Neighbors with non-Muslims Narrated from Abdullah bin 'Amr Al Ash: "He slaughtered a goat. He then said to a young man: 'I will give some to our Jewish neighbors'. The young man said: 'Huh? You give to our neighbors the Jews? I heard the Prophet sallallaahu'alaihi Wasallam said 'Gabriel always advised me about neighbors, so I thought that the neighbor would get a share of inheritance' "(Narrated by Al Bukhari in $\mathrm{Al}$ Adabul Mufrad 78/105).

6) Rahmatan lil 'Alamin values in profession (Meeting 6)

a) Guidance for profession with Rahmatan lil 'Alamin in the Al-Qur'an

In Surat At-Taubah verse 105, Allah the Exalted says (which means): "And say," Work for you, then Allah and His Messenger and the believers will see your work and you will lose to (Allah) Who knows the unseen and the real, then He tells you what you have to do it "(Surat at-Tawbah verse 105).

b) Guidance for profession with Rahmatan lil 'Alamin in Hadith

i. Adab in trading Rasulullah SAW said: "Narrated from Ibn Umar r.a he said: Verily the Messenger of Allah SWT Buying merchandise arrived on the market. This is from Ibn Numair. Whereas according to other narrators, the real Prophet SAW. Buy merchandise before it is marketed. '(Muslim, Shahîh Muslim, V / 5, hadith number 3894).

ii. Halal profession The Messenger of Allāh SWT said: "Seeking halal sustenance is obligatory to do fard worship." (H. Ath-Thabrani and AlBaihaqi).

iii. Totality in the profession in accordance with Islamic principles Rasulullah SAW said: "Verily Allah records servants who are working and skilled. Whoever takes the trouble to make a living doing the same thing with a mujahid in the way of Allah. "(Hadith narrated by Ahmad).

iv. Enthusiastic in carrying out the profession Rasulullah SAW said: "Be eager to do something useful for you and help God, and do not be lazy" (HR. Muslim). 
7) Rahmatan lil 'Alamin values with the environment (Meeting 7)

a) Rahmatan lil 'Alamin Guidance on the Environment

In the Qur'an In Sura Al Rum 41-42, as follows: "Corruption has appeared throughout the land and sea by [reason of] what the hands of people have earned so He may let them taste part of [the consequence of] what they have done that perhaps they will return [to righteousness].(41) Say, [O Muhammad], "Travel through the land and observe how was the end of those before. Most of them were associators [of others with Allah ] (42)" (QS. Ar Rum 41-42).

\section{b) Banning Land Abandonment Meaning}

Hadith Jabir bin Abdullah r.a. he said: There were a number of people from us who had land deposits. Then they said: We will rent the land (to manage it) with a third of the proceeds, a quarter and a second. Rosulullah S.a.w. said: Whoever owns the land, let him plant it or leave it to his brother (to be used), so if he is reluctant, let him pay attention to himself taking care of the land. "(HR. Imam Bukhori in the book of Al-Hibbah).

\section{c) Tree Planting (reforestation) Recommended Steps}

Hadith from Anas r.a. he said: Rosulullah S.A.W. said: A Muslim does not plant a tree or sow seeds to the ground, then a bird or human or animal comes to eat a portion of it, but what is eaten is alms ". (HR. Imam Bukhari).

8) Rahmatan lil 'Alamin Fellow Humans Being values (Meeting 8)

In al Hujurât verse 13, Allah the Exalted says as follows: "O mankind, indeed We have created you from male and female and made you peoples and tribes that you may know one another. Indeed, the most noble of you in the sight of Allah is the most righteous of you. Indeed, Allah is Knowing and Acquainted."

\section{9) Rahmatan lil 'Alamin Family Values (Meeting 9)}

Managing a sakinah, mawaddah, and rahmah family can be done by paying attention to 9 (nine) important things, namely: (1) Mutual respect; (2) Mutual complement; (3) Strengthening patience, (4) Maintaining healthy jealousy; (5) Never stop learning; (6) Generous towards couples; (7) Maintaining appearance; (9) Understanding couples psychological conditions; (10) Saying thank you. (Lukman A. Irfan, 2007)

\section{0) Rahmatan lil 'Alamin values of Worship (Meeting} 10)

a) Guidance for worshiping with Rahmatan lil 'Alamin

In the Qur'an Devotion to Allah SWT is not just prayer, but as Allah SWT says: Righteousness is not that you turn your faces toward the east or the west, but [true] righteousness is [in] one who believes in Allah, the Last Day, the angels, the Book, and the prophets and gives wealth, in spite of love for it, to relatives, orphans, the needy, the traveler, those who ask [for help], and for freeing slaves; [and who] establishes prayer and gives zakah; [those who] fulfill their promise when they promise; and [those who] are patient in poverty and hardship and during battle. Those are the ones who have been true, and it is those who are the righteous. (Surah Al-Baqarah: 177)

\section{b) Rahmatan lil 'Alamin worship service}

In Hadith From 'Aisha, the Prophet sallallaahu' alaihi wa sallam said: "O people, do practice according to your abilities. Because God is not bored until you feel bored. (Know that) the deeds that are most loved by Allah are continuous (steady) practices, although few. "(HR. Imam Muslim No. 782)

\section{DISCUSSION}

The Dissemination Process of Rahmatan lil 'alamin values The number of subjects who followed this dissemination amounted to 17 people. The highest number counted 27 people and the lowest number counted 11 people. The process of disseminating the value of Rahmatan lil 'alamin changed from the original plan. This happened in the pre-test and posttest; from the plan used a questionnaire, converted into an interview. This change is caused by the condition of the service subject, who on average were over 45 years of age, who were less familiar with writing habits at events such as recitation which is considered non-formal activities. Instructors took the initiative by using non-structured interviews to avoid the impression of being too formal in the recitation process.

From the interview results, the instructors done rahmatan lil 'alamin values well, and it can be observed with the daily behavior of subjects who routinely followed this dissemination. The burial of rahmatan lil 'alamin's values only limited to the dedication carried out by the instructors. It is firmly stated that there are some that are seen and observed. This is due to hearing and enjoying from the service and of course because Allah SWT gives guidance and blessed so that they can implement the values of grace. This is observed among the worshiper in land use, the more harmonious relationships within the family, the harmonious relationship with neighbors, the harmonious relationship with non-Muslim human beings, and the honesty and perseverance of subjects in carrying out their profession or occupation.

Can rahmatan lil alamin's values be comprehensively carried out by the subject? As with the values of faith in the soul of a person that the Messenger of Allāh, stated that faith falls and rises, the emission of rahmatan lil 'alamin values by the subject also sometimes falls and rises. The dissemination of Rahmatan lil 'alamin values is eroded by social media information that is intolerant.

\section{A. Challenges for the Desimination of Rahmatan lil 'Alamin}

Values Unstructured interviews conducted by instructors also found that some subjects who were familiar with social media such as Facebook and whatsapp application experienced more confusion because they also input a lot of information and sometimes hoaxes. Their confusion can be seen from the time when Jakarta Election, the capital of Indonesia, was intensified. This causes confusion. The servant only gives one reinforcement that in the state relationship, the agreement that has been used as the rule of law is guided. This is in accordance with the Medina Charter which the Prophet Muhammad SAW made as a joint guidance in Madinah with other people.

\section{CONCLUSION}

Dissemination of rahmatan lil 'alamin values is well planted with the PBL method, and this can be observed with the subject's daily behavior. Subjects are increasingly able to 
use the land wisely, have increasingly harmonious relationships in the family, harmonious relations with neighbors, harmonious relations with non-Moeslim people, and subject honesty and perseverance in carrying out their profession or work. Rahmatan lil 'alamin values dropped and went up. Further activities need to be carried out as an effort to maintain consistency or istiqomah in actualizing rahmatan lil 'alamin values.

\section{ACKNOWLEDGMENT}

The authors would like to express their gratitude to: (1) Directorate of Research and Community Service of the Islamic University of Indonesia: (2) Islamic Education Study Program, Faculty of Islamic Studies UII; (3) Ahmad Prakosa, student of the Islamic Education Study Program, Faculty of Islamic Studies; (4) Assembly of Dhikr and Taklim Ya Badi ', Kalitirto Berbah, Sleman, DIY.

\section{REFERENCES}

[1] Abdillah, Abi, Imam. Without year. Sahih Bukhari. Bairut Lebanon. Darul Kutub.

[2] Abu Husain Nuslim bin Al Hajjaj Ibnu Muslim Al Qusyairi An Naisaburi. Without Year. Sahih Muslim. Beirut: Dar Al Kutub Al Ilmiyah.

[3] Ahmad bin Muhammad bin Hambal. 1995. Al-Musnad. Darul Hadis Al-Qohiroh.
[4] Arends, R. 1987. Clasroom Instruction and Management. New York: Mc Graw-Hill Companies.

[5] Gulen, Muhammad Fethulleah. 2014. Islam Rahmatan lil Alamin, Menjawab Pertanyaan dan Kebutuhan Manusia Eds.4. Jakarta: Republika.

[6] Katsir, Al-Imam Al-Jalil al-Hafidz Imaduddin Abi Fida' Ismail bin Katsir ad-Dimasyqi. Without year. Tafsir Al-Qur'anul Adzim. Darul Al-Hadis Al-Qohiroh. Without publisher city.

[7] Lukman Ahmad Irfan. "The Implementation Of A Problem Based Learning In Improving Adaptive Competence On The Subject Of Education For Special Need Students At Islamic University Indonesia." Proceedings of 99th The IIER International Conference, Mecca, Saudi Arabia, 23rd-24th March 2017, ISBN: 978-93-86291$88-2$.

[8] Lukman A. Irfan. 2007. Worship Guidance Series, A Marriage. Yogyakarta: Pustaka Insani Madani.

[9] Lukman. 2016. Interpretation of Ayat Rahmatan lil 'Alamin According to Ahlu Sunnah, Muktazilah, Shia, and Wahabi. Millah Islamic Studies Journal. Edisi Februari 2016.

[10] Nisaul Azmi Hajar, A.Y. Djoko Darmono, Atik Catur Budiati. 2016. Application of Problem Based Learning (PBL) Learning Model to Improve Learning Outcomes of Class X-3 Students in Sociology Subjects of High School District of 2015/2016 Academic Year. Study Program of Anthropology Sociology Education, Faculty of Teacher Training and Education, Sebelas Maret University.

[11] Suci, Ni Made. 2008. Application of the PBL Model to Improve Learning Participation and Learning Outcomes. Accessed through www.freewebs.com/santyasa/lemlit/PDF_files/PENDIDIKAN

[12] Translations Al-Quran verses are taken from the site www.quran.com. 